\title{
The Impact of Reading Strategy Use on EFL College Students
}

\author{
Ching-Ying Lin*, Yu Hung Pan \\ Department of Applied English, National Pingtung University, Pingtung, Taiwan
}

*Corresponding Author: Ching-Ying Lin, Department of Applied English, National Pingtung University, Pingtung, Taiwan

\begin{abstract}
The purpose of this study was aimed to probe the question whether language reading strategies use among Taiwanese EFL College students differ according to different genders and the differences of frequency using types of reading strategies. The study focused on one hundred EFL college students coming from four colleges located in Taiwan. The findings showed that different types of EFL college students would choose different categories of reading strategies. In this study, the orders of the subjects used in English learning were Problem-solving strategy, Global strategy and Support strategy. Because of the different learning styles and learning skills, EFL college students would adopt different categories of reading strategies. In addition, all of the participants feel "Sentence structure" is the most reading difficulties in English. The result is the same as the order of the women's. However, men feel "reading material is too lengthy" is the most difficult. The study revealed all of the participants think "grammar" is the least difficult for reading English. Therefore, the result also indicated that the grammar knowledge is the best part for EFL college students in reading English. Pedagogical implications and some suggestions for further study are then supplies conclude in this research.
\end{abstract}

Keywords: Reading Strategy, EFL College Students, Gender Difference

\section{INTRODUCTION}

\subsection{Background}

The study of learner strategy, started by reference[1] by giving a description of successful language learners, has already been carried out since 1975. There are three different types of good learner conducted by him. (1) The good language learner is willing and excels at guessing. (2) The good language learner excels at communicate with other. (3) The good language learner is often not inhibited [1]. Based on Rubin findings, the researchers are trying to prove if these findings are also workable on EFL learners in the classroom, particularly at university. Teaching reading has ever since gained much attention in the core principle of the grammar translation method. Reading skills as reference[2] stated was mostly thought of as comprehensible input which is the mere reason to paying the way for gaining knowledge in various skills, especially speaking and writing. In addition, voluntary reading was emphasized by reference[2] as an approach to covering a variety of communicative language competence to academic language competence. This study aims to convey different sorts of reading strategies that are frequently used by advanced English learners in Taiwan EFL college students. When it comes to implementations of the finding of the current study, it benefits teachers to develop teaching methods and has positive effect on curriculum design, Up to now, few study has resembled the current one conducted on Taiwan advanced English language learners, especially Taiwan college students.

\subsection{Problem Statement}

The problems to be addressed are what Taiwan college students use reading strategies most or least, and what college students have difficulties while reading English. The purpose of the study is to provide a review of the research literature related to the importance of effective strategies in EFL reading instructions for EFL college students in Taiwan, and how to make applications for improving reading comprehension for Taiwanese EFL college students.

\subsection{Purpose of the Study}

The purpose of this study was to explore EFL college student's English reading strategy use, reading difficulties between National University and Private University English major students. 


\subsection{Research Questions}

- What reading strategies do Taiwanese college students use most or least?

- What difficulties do college students have while reading in English?

\subsection{Significance of the Study}

For English learners, reading ability is the essential skills for academic purpose, especially in EFL environments [3-7]. In addition, the importance of reading strategies has been emphasized by a lot of researchers [8-12]. The study of effective strategies is important to the practice of English courses. This study will make an impact on the use of effective learning strategies in reading. It is very important for instructors to seek for the information related to the effective reading strategies known as " best practices". Therefore, it is necessary that instructors should explore and improve the quality of teaching reading courses.

\section{LITERATURE REVIEW}

\subsection{Reading Strategies}

Reading strategies is defined by reference[13] as purposeful and cognitive actions which learners take when they read to aid them in making and keeping meaning. Based on reference $[14,15]$, reading strategies are regarded as conscious behaviors that readers use before, during, and after reading to obtain the meaning from the text. Readers use particularly learned procedures to promote active, competent, and intentional reading. To help learners understand better, reference[16, 17] stated that reading comprehension strategies are seen as effective instruments. They can also be used as conscious plans and activities that help learners develop and control their comprehension of texts. Depending on reference[18], successful readers use reading comprehension strategies as conscious schemes to understand a text. Using reading strategies help learners become energetic readers who are in control of their own reading comprehension. Reference[19] stated that reading strategies offered path to understanding the meanings of a text. Reading strategies are defined as the mental tasks that readers apply to make meaning from the text [20]. Several factors effect reading strategy use for instance readers' previous knowledge [21], text type [22] and readers' proficiency[23].

So far, there are various ways to classify reading strategies[6, 24, 25] and conducted different categories, Survey of Reading Strategy[26, 27]Metacognitive Awareness of Reading Strategies Inventory [26]which affect students language learning and performance. Reference[6] mentioned three different types of reading strategies, including cognitive, metacognitive, and supportive. Moreover, the researchers gave these three types of reading strategy new name, global reading strategies (GLOB), problem-solving reading strategies (PROB), and support reading strategies (SUP)[26, 27]. GLOB including set a goal to read or predict the meaning. PROB including using context to realize the meaning of word, using re-read to understand the meaning of the context, SUP using some instruments to assist reading, taking notes, underlining the key points to assist reading.

\subsection{The Use of Strategy-Base Instruction}

Reading comprehension skills can be gained easily through positive communication between the instructor and the learner. Explicit strategy instruction is a useful approach of teaching students at all level and competencies. This instruction method is consistent with the principles of Vygotsky's theory social constructivism [28]. Social interaction can improve learners' cognitive development when they engage in interpersonal communication and discussions [29]. Oral discussion during classes benefits build a vocabulary that, over time, becomes internalized as inner speech [30]. This internalization process becomes an integral part of the cognitive skill repertoire. While instructors are involved in the direct instruction of specific reading methods, they must monitor their learners progress, and continually give the with encouragement. Finally, the overall learning outcome of direct instruction of strategies is to enable students to select from various strategies themselves in a flexible and efficient way.

Reading strategy teaching has been subject to extensive research [31-35]. For instance, reference [36] investigated Vygotsky's internalization and egocentric speech as related to the oral reading and silent reading strategies according to their importance to such processes as decoding and encoding. The researchers stated that "Oral reading is better for comprehension only after a couple years schooling." [36]. Research [37-39] reveals that low level readers can comprehend orally presented texts better than silent reading. Moreover, the poor reader presents much better on inferential questions than on 
literal ones. Furthermore, they suggested that an average reader comprehends better during silent reading than during oral reading by tackling these two types of questions as efficiently as they can. Nevertheless, they found a good reader is stronger than the poor and average reader in both oral reading and silent reading on various scales of comprehension, indicating superior skills of elaboration. To sum up, they found that reading for elaboration or details, is a significant indicator of competence when it comes to literal comprehension.

\section{Methodology}

The current study aimed to examine strategy use and reading difficult between National University and Private University English major college students. This part will describe research design, participants, instrument, semi-structured interviews, procedures, data analyses.

\subsection{Research Design}

The purpose of this study was to explore English reading strategy use and reading difficulties for National University and Private University English major students. In order to explore student reading strategy use and reading difficult, one questionnaire was developed and modified in this research. Moreover, semi-structured interview was implemented to examine further information on reading strategy use and reading difficult for EFL learners.

\subsection{Participants}

A total of one hundred college students participated in this study including fifty National University English major students and fifty Private University English major students. They were recruited from four universities in Taiwan including two National Universities and two Private Universities.

\subsection{Instruments}

\subsubsection{Reading Strategy Questionnaire}

The data for this article were collected through a questionnaire from the survey of reading strategies. It comprises 28 items and four open-ended questions. 28 questions divided into three categories: global reading strategies, problem-solving strategies and support strategies. Question 1-12 are the global reading strategies category, question 13-19 are problem-solving category, and question 20-28 are support strategies category. The questionnaire items in the study involved 5-point Likert scale that in divided from 1 (strongly disagree) to 5 (strongly agree) Each questions following from 1 (strongly disagree) to 5 (strongly agree).

\subsubsection{Semi-structured Interviews}

In order to gain further information concerning reading strategy use and reading difficult between National University and Private University English major students. The total participants were one hundred college students. There were some interview questions for the participants including:

- Do you like English? How do you think your English ability?

- Do you think reading strategy use is helpful for your English reading? May you give some examples?

- What difficulties do you have while reading in English?

- While facing reading problems, what strategy will you use to solve the problem?

\subsection{Procedures}

In order to enhance the accuracy of the questionnaire, a pre-test for 10 people to make sure questionnaire was easily understood and no mistakes. The survey was implemented in October 2018. The researcher explained the main goal of the study and instructed the students to fill out background information and the questionnaire. Students needed to accomplish the survey in 20 minutes. Students needed to supply honest answer to fill out the questionnaire of reading strategy use and difficulties of reading. Later, all the completed questionnaires were examined. On the other hands, the researchers will select one hundred students to have semi-structured interviews. Fifty students were female and fifty students were male. They were taken from National University and Private University English major class. Each of them would have 10 minutes to complete four interview questions. 


\subsection{Data Analyses}

The general design of the study included quantitative and qualitative parts. In the current study, all of the collected data were calculated by the Statistic Packages for the Social Science (SPSS). In order to probe the first research question, the descriptive statistics (frequencies, means and standard deviations) were calculated for overall reading strategies use of participants. The interview would be proceeding at the end of the survey in order to get learners' perceptions towards reading strategies use.

\section{RESUlT}

The data of reading strategy use questionnaire was gathered from 100 college students including 50 National university students and 50 Private University students.

\subsection{Research Questions 1}

\subsubsection{What Reading Strategies do Taiwanese College Students Use most or least?}

In Table 1, college students in general used the type of Problem-solving Strategy was the most $(\mathrm{M}=3.97)$, and in general the type of the Support Strategy was the least. $(\mathrm{M}=3.32)$

Table1. Overall and Specific Types of Reading Strategy Use $(N=100)$

\begin{tabular}{|l|l|l|l|}
\hline Type & Rank & M & SD \\
\hline Global strategy & 2 & 3.51 & .83 \\
\hline Problem-solving & 1 & 3.97 & .76 \\
\hline Support strategy & 3 & 3.32 & .80 \\
\hline Overall & & 3.31 & .54 \\
\hline
\end{tabular}

As showed in Table 2, the top one of global strategy is item 5 (Global strategy) "I use some prior knowledge to help me to understand the article." $(M=3.77)$ This high frequency showed that students in order to understand what they are read, most college students would use some knowledge such like grammar knowledge, structure knowledge to help them more easily to understand the article meaning. And it had $70 \%$ of agreement in this item. The second rank of global strategy was item 7 (Global strategy) "I use some clues form article to increase my understanding." $(\mathrm{M}=3.73)$ This high frequency showed that most college students would use some clues from the article to speculate the meaning or a word. It would and help students to understand the articles. And it had 69\% of agreement in this item. The third rank of global strategy was item 8 (Global Strategies) "I use features in text to help me get key point more easily." $(\mathrm{M}=3.63)$ This high frequency showed that most college students would use some features to catch key information of the article and help them read easier. And it had $62 \%$ of agreement in this item. However, the means of item 11 (Global Strategies) "I check my guessing is correct or incorrect." $(\mathrm{M}=2.70)$ did not have high mean. It got the second-last rank in global strategies this section. This low frequency showed that most college students would not inspect their guess of the article is right or wrong. On the other hands, the means for item 12 (Global Strategies) was the last rank "I think about the information what I read rather than passively accept." $(\mathrm{M}=2.36)$ This low frequency showed that most college students would think about the message given by the article instead of accepting it in its entirety.

As showed in Table 2, the top one of problem-solving strategy first rank was item 17 (Problemsolving) "When I read, the article becomes more difficult, re-read strategy would help me increase my understanding." ( $\mathrm{M}=3.60)$ This high frequency showed that student's think when text becomes more difficult students would use re-read strategy to help them enlarge understanding of the article. And it had $62 \%$ of agreement in this item. The second rank of problem-solving strategy was item 18 (Problem-solving) "I guess the meaning of text while reading, especially unknown words." $(\mathrm{M}=3.51)$ This high frequency showed that most college students would use guessing during their reading especially unknown words or phrases. And it had $60 \%$ of agreement in this item. The third rank of problem-solving was item 19 (Problem-solving) "When I lost concentration, I will try to get attention." (M=3.49) This high frequency showed that most college students would try to get attention when they lose concentration while reading. And it had 58\% of agreement in this item. On the other hands, the means of item 15 (problem-solving) "When I read, I stopped to think about what I read." $(\mathrm{M}=2.48)$ did not have high mean. It got the second-last rank in problem-solving strategies. This low frequency showed that most college students would not stopped to think about the article during their 
reading. And the means of item 16 (Problem-solving) was the last rank "I organize information form article which could assist me remember the article." $(\mathrm{M}=2.24)$ This low frequency showed that most college students would not use picture or visualize information to help them remember what they read. As showed in Table 2, the top three of support strategy first rank was item 20 (Support Strategy) "When I read, I take note to help me understand the information of the article." $(\mathrm{M}=3.87)$ This high frequency showed that students would take note of the key words or the main ideas while reading. Students would take note to help them understand the meaning of the article. And it had $67 \%$ of agreement in this item. The second rank of problem-solving strategy was item 23 (Problem-solving) "I use dictionary or tool to help me while reading." $(M=3.67)$ This high frequency showed that most college students would use some tool to help them understand what they are read. And it had 65\% of agreement in this item. The third rank of problem-solving was item 21 (Problem-solving) "I use some method such as circle or underline to help me understand the article." $(\mathrm{M}=3.51)$ This high frequency showed that most college students would underline and circle information during their reading and to help them reading. And it had 58\% of agreement in this item. However, the means of item 26 (Support Strategy) "I will ask some question to myself to make sure I understand the article." $(M=2.70)$ did not have high mean. It got the second-last rank in support strategy this section. This low frequency showed that most college students would not ask themselves question while reading. And the means of item 22 (Support Strategies) was the last rank "I will use read aloud strategy when the article becomes more difficult." ( $M=2.67)$ This low frequency showed that most college students would not use read aloud to help them understand the article meaning while reading.

Table2. The Top Three and bottom Two Items of Each Type Strategy $(N=100)$

\begin{tabular}{|c|c|c|c|c|c|c|c|}
\hline Type & Use & Item Description & $\mathbf{M}$ & SD & Agree(\%) & Unsure(\%) & Disagree(\%) \\
\hline \multirow[t]{5}{*}{ Global } & Most & $\begin{array}{l}\text { 1. I use some prior knowledge to help } \\
\text { me to understand the article. (5) }\end{array}$ & 3.77 & 1.13 & 70 & 17 & 14 \\
\hline & & $\begin{array}{l}\text { 2. I use some clues form article to } \\
\text { increase my understanding. (7) }\end{array}$ & 3.73 & 1.07 & 69 & 16 & 14 \\
\hline & & $\begin{array}{l}\text { 3. I use features in text to help me get } \\
\text { key point more easily. (8) }\end{array}$ & 3.63 & 1.07 & 62 & 16 & 12 \\
\hline & Least & $\begin{array}{l}\text { 1. I check my guessing is correct or } \\
\text { incorrect. (11) }\end{array}$ & 2.70 & 0.96 & 15 & 29 & 56 \\
\hline & & $\begin{array}{l}\text { 2. I think about the information what I } \\
\text { read rather than passively accept. (12) }\end{array}$ & 2.36 & 1.04 & 13 & 30 & 47 \\
\hline \multirow[t]{5}{*}{$\begin{array}{l}\text { Problem- } \\
\text { solving }\end{array}$} & Most & $\begin{array}{l}\text { 1. When I read, the article becomes } \\
\text { more difficult, re-read strategy would } \\
\text { help me increase my understanding. } \\
(17)\end{array}$ & 3.60 & 0.10 & 62 & 20 & 18 \\
\hline & & $\begin{array}{l}\text { 2. I guess the meaning of text while } \\
\text { reading, especially unknown words. } \\
(18)\end{array}$ & 3.51 & 1.14 & 60 & 17 & 23 \\
\hline & & $\begin{array}{l}\text { 3. When I lost concentration, I will try } \\
\text { to get attention. (19) }\end{array}$ & 3.49 & 1.17 & 58 & 16 & 26 \\
\hline & Least & $\begin{array}{l}\text { 1. When I read, I stopped to think } \\
\text { about what I read.(15) }\end{array}$ & 2.48 & 0.95 & 22 & 26 & 52 \\
\hline & & $\begin{array}{l}\text { 2. I organize information form article } \\
\text { which could assist me remember the } \\
\text { article. (16) }\end{array}$ & 2.24 & 1.24 & 20 & 23 & 57 \\
\hline \multirow[t]{5}{*}{ Support } & Most & $\begin{array}{l}\text { 1. When I read, I take note to help me } \\
\text { understand the information of the } \\
\text { article. }(20)\end{array}$ & 3.87 & 1.03 & 67 & 21 & 12 \\
\hline & & $\begin{array}{l}\text { 2. I use dictionary or tool to help me } \\
\text { while reading. ( } 23 \text { ) }\end{array}$ & 3.67 & 1.06 & 65 & 17 & 18 \\
\hline & & $\begin{array}{l}\text { 3. I use some method such as circle or } \\
\text { underline to help me understand the } \\
\text { article.(21) }\end{array}$ & 3.51 & 1.05 & 58 & 22 & 20 \\
\hline & Least & $\begin{array}{l}\text { 1. I will ask some question to myself to } \\
\text { make sure I understand the article. (26) }\end{array}$ & 2.70 & 0.96 & 22 & 28 & 50 \\
\hline & & $\begin{array}{l}\text { 2. I will use read aloud strategy when } \\
\text { the article becomes more difficult. (22) }\end{array}$ & 2.67 & 1.04 & 20 & 22 & 58 \\
\hline
\end{tabular}




\subsection{Research Questions2}

What difficulties do college students have while reading in English?

In research question 2 we could infer from the questionnaire. Table 3 revealed that "Sentence structure" ( $\mathrm{f}=57)$ is the most reading difficulties in English for EFL college students. It has highly percentage $57 \%$ of the entire open-ended question. The second one is that "Reading material is too lengthy" ( $\mathrm{f}=37)$. The third one is "Insufficient vocabulary knowledge" $(\mathrm{f}=16)$. The last one is that "Grammar problems" ( $\mathrm{f}=8)$ and its percentage is $8 \%$.

Table3. The Reading Difficulties for Total learners $(N=100)$

\begin{tabular}{|l|l|l|l|}
\hline Ranking & \multicolumn{1}{|c|}{ Category } & \multicolumn{1}{c|}{ f } & \multicolumn{1}{c|}{$\%$} \\
\hline 1 & Sentence structure & 57 & $57 \%$ \\
\hline 2 & Reading material is too lengthy & 37 & $37 \%$ \\
\hline 3 & Insufficient vocabulary knowledge & 16 & $16 \%$ \\
\hline 4 & Grammar problems & 8 & $8 \%$ \\
\hline Total & & 100 & $100 \%$ \\
\hline
\end{tabular}

Table 4 revealed that "Reading material is too lengthy" ( $\mathrm{f}=24)$ is the most reading difficulties in English for male EFL college students. It has highly percentage $48 \%$ of all the open-ended question. The second one is that "Sentence structure" $(\mathrm{f}=20)$. The third one is "Grammar problem" $(\mathrm{f}=7)$. The last one is that "Insufficient vocabulary knowledge" ( $\mathrm{f}=4)$ and its percentage is $8 \%$.

Table4. The Reading Difficulties for Male learners $(N=50)$

\begin{tabular}{|l|l|l|l|}
\hline Ranking & Category & f & $\%$ \\
\hline 1 & Reading material is too lengthy & 24 & $48 \%$ \\
\hline 2 & Sentence structure & 20 & $40 \%$ \\
\hline 3 & Grammar problems & 7 & $14 \%$ \\
\hline 4 & Insufficient vocabulary knowledge & 4 & $8 \%$ \\
\hline Total & & 50 & $100 \%$ \\
\hline
\end{tabular}

Table 5 revealed that "Sentence structure" ( $\mathrm{f}=33$ ) is the most reading difficulties in English for female EFL college students. It has highly percentage $66 \%$ of the entire open-ended question. The second one is that "Reading material is too lengthy" ( $\mathrm{f}=17)$. The third one is "Insufficient vocabulary knowledge" $(\mathrm{f}=9)$. The last one is that "Grammar problem" $(\mathrm{f}=4)$ and its percentage is $8 \%$.

Table5. The Reading Difficulties for Female learners $(N=50)$

\begin{tabular}{|l|l|l|l|}
\hline Ranking & \multicolumn{1}{|c|}{ Category } & \multicolumn{1}{c|}{ f } & \multicolumn{1}{|c|}{$\%$} \\
\hline 1 & Sentence structure & 33 & $66 \%$ \\
\hline 2 & Reading material is too lengthy & 17 & $34 \%$ \\
\hline 3 & Insufficient vocabulary knowledge & 9 & $18 \%$ \\
\hline 4 & Grammar problems & 4 & $8 \%$ \\
\hline Total & & 50 & $100 \%$ \\
\hline
\end{tabular}

\section{DISCUSSION}

The purpose of this study was to explore EFL college student's English reading strategy use, reading difficulties between National University and Private University English major students. In this survey, one hundred Taiwan college students $(\mathrm{M}=50, \mathrm{~F}=50)$ were asked to fill out 28-item questionnaires and four interview questions. Discussion of the finding and the important results are presented in this part. Pedagogical implications and some suggestions for further study are then supplies conclude in this research.

\subsection{Discussion on Important Findings}

The researcher got the findings as follow:

\subsubsection{The Most and the Least Reading Strategies EFL College Students Use}

The conclusion is that different types of EFL college students would choose different categories of reading strategies. In this study, the orders of the subjects used in English learning were problemsolving strategy, Global strategy and Support strategy. Because of the different learning styles and learning skills, EFL college students would adopt different categories of reading strategies. 


\subsubsection{EFL College Students Reading Difficulties in English}

To sum up, all of the participants feel "Sentence structure" is the most reading difficulties in English. The result is the same as the order of the women's. However, men feel "reading material is too lengthy" is the most difficult. The study revealed all of the participants think "grammar" is the least difficult for reading English. Therefore, the result also indicated that the grammar knowledge is the best part for EFL college students in reading English.

\subsection{Pedagogical Implications}

EFL reading instructors can take advantages from this study through designing proper strategy-based reading teaching approach that is grounded in schema theory and learning method, and by providing various of reading modes to cater for the styles and needs of learning of various students. Instructors should divide students into small groups in reading classes and give their students the opportunity for oral or silent reading depending on which meets their learning preferences. This arrangement can be conducted by choosing oral reading activities for low visual students, especially on hard reading texts. Also, it could be suggested that high auditory students should be promoted to read aloud because in this study their scores were consistently better compared to the lower auditory students, despite the complications showed by reference [30].

Considering learning styles and preferences, it will not beneficial for all types of learners by using silent reading and oral reading in isolation. A teacher may plan oral reading activities especially for low visual EFL students and for high auditory EFL students. Besides, the EFL instructors can choose either silent or oral reading activities for other learners. Finding from this study reveal that EFL students can benefit both silent and oral reading strategies utilized in combination through small cooperative groups. Consequently, reading teachers can be flexible in preplanning various reading strategies to make their teaching activities richer and make their students benefit from them. For instance, a reading teacher can gain information about learners with similar learning preferences and assign them to work in groups to be offered with miscellaneous reading activities. Then they can be encouraged to utilize effective reading strategies that are proper for each group, considering their preferred reading methods.

All in all, reading course designers should assist reading teachers to examine the learning styles and preferences of their learners by learning styles inventories before they start their first reading lessons. Then, reading teachers should plan their lessons considering the learners reading and writing scores on previous performance tests in the skills and their preferred learning styles as well. Curriculum designers should encourage reading teachers to be flexible in the reading materials for teaching and choosing the suitable teaching strategies for their students learning styles.

\subsection{Suggestions for Future Research}

Hence, the researchers believe that through the proposed method the EFL student will be easier in following English course in the classroom. Furthermore, it strongly suggests that EFL learner tend to use various strategies to make learning activity more functional and pleasant. Last but not least, it is suggested for the next researcher to conduct deeper researches which are related to learner learning strategies of good EFL learner with a greater number and different educational background of studies.

\section{REFERENCES}

[1] J. Rubin, "What the" good language learner" can teach us," TESOL quarterly, pp. 41-51, 1975.

[2] S. D. Krashen, "Inquiries and insight: Essays on second language teaching, bilingual education, literacy. Hayward," ed: CA: Alemany Press, 1985.

[3] P. L. Carrell, J. Devine, and D. E. Eskey, Interactive approaches to second language reading. Cambridge University Press, 1988.

[4] W. Grabe, "Current developments in second language reading research," TESOL quarterly, vol. 25, no. 3, pp. 375-406, 1991.

[5] T. h. He, "Reading for different goals: the interplay of EFL college students' multiple goals, reading strategy use and reading comprehension," Journal of Research in Reading, vol. 31, no. 2, pp. 224-242, 2008.

[6] R. Sheorey and K. Mokhtari, "Differences in the metacognitive awareness of reading strategies among native and non-native readers," System, vol. 29, no. 4, pp. 431-449, 2001.

[7] R. Sheorey, "An examination of language learning strategy use in the setting of an indigenized variety of English," System, vol. 27, no. 2, pp. 173-190, 1999. 
[8] N. J. Anderson, Exploring second language reading: Issues and strategies. Heinle \& Heinle, 1999.

[9] N. K. Duke and P. D. Pearson, "Effective practices for developing reading comprehension," Journal of education, vol. 189, no. 1-2, pp. 107-122, 2009.

[10] W. P. Grabe and F. L. Stoller, Teaching and researching: Reading. Routledge, 2013.

[11] M. Pressley, "Metacognition and self-regulated comprehension," What research has to say about reading instruction, vol. 3, pp. 291-309, 2002.

[12] C. Nuttall, Teaching reading skills in a foreign language. ERIC, 1996.

[13] L. Baker and A. L. Brown, "Metacognitive skills and reading," Handbook of reading research, vol. 1, no. 353, p. V394, 1984.

[14] M. Pressley, "Reading instruction that really works," ed: New York, NY: The Guilford Press, 2006.

[15] T. Trabasso and E. Bouchard, "Teaching readers how to comprehend text strategically," Comprehension instruction: Research-based best practices, pp. 176-200, 2002.

[16] M. Pressley and C. Block, "Summing up: What comprehension instruction could be," Comprehension instruction: Research-based best practices, pp. 383-392, 2002.

[17] E. O. Keene and S. Zimmermann, Mosaic of thought: Teaching comprehension in a reader's workshop. ERIC, 1997.

[18] C. Adler, "Put reading first: The research blocks for teaching children to read," ed: Jessup, MD: National Institute for Literacy, Partnership for Reading, 2001.

[19] S.-F. Lai, C.-H. Li, and R. Amster, "Strategically Smart or Proficiency-Driven? An Investigation of Reading Strategy Use of EFL College Students in Relation to Language Proficiency," Contemporary Issues in Education Research, vol. 6, no. 1, pp. 85-92, 2013.

[20] N. Anderson, "Scrolling, Clicking, and Reading English: Online Reading Strategies in a Second/Foreign Language. The Reading Matrix. 3 (3): 1-33," ed, 2003.

[21] R. Pritchard, "The effects of cultural schemata on reading processing strategies," Reading Research Quarterly, pp. 273-295, 1990.

[22] B.-c. Chen, "Discrepancy of reading strategies for academic purposes between high achievers and low achievers at a junior college in Taiwan," in Proceeding of the eight International Symposiums on English Teaching, Taipei, Grane, 1999.

[23] S. B. Kletzien, "Strategy use by good and poor comprehenders reading expository text of differing levels," Reading research quarterly, pp. 67-86, 1991.

[24] R. Oxford, "Language learning strategies," New York, vol. 3, 1990.

[25] J. M. O'malley, M. J. O'Malley, A. U. Chamot, and J. M. O'Malley, Learning strategies in second language acquisition. Cambridge university press, 1990.

[26] K. Mokhtari and C. A. Reichard, "Assessing students' metacognitive awareness of reading strategies," Journal of educational psychology, vol. 94, no. 2, p. 249, 2002.

[27] K. Mokhtari and R. Sheorey, "Measuring ESL students' awareness of reading strategies," Journal of developmental education, vol. 25, no. 3, pp. 2-11, 2002.

[28] B. Rogoff, Apprenticeship in thinking: Cognitive development in social context. Oxford university press, 1990.

[29] R. Ben-Ari and P. Kedem-Friedrich, "Restructuring heterogeneous classes for cognitive development: Social interactive perspective," Instructional science, vol. 28, no. 2, pp. 153-167, 2000.

[30] L. S. Vygotsky, "Thought and language (A. Kozulin, trans.)," ed: Cambridge, ma: mit Press, 1986.

[31] M. R. Ahmadi, H. N. Ismail, and M. K. K. Abdullah, "The Importance of Metacognitive Reading Strategy Awareness in Reading Comprehension," English Language Teaching, vol. 6, no. 10, pp. 235-244, 2013.

[32] E. H. Hiebert, S. J. Samuels, and T. Rasinski, "Comprehension-based silent reading rates: What do we know? What do we need to know?," Literacy Research and Instruction, vol. 51, no. 2, pp. 110-124, 2012.

[33] Rehman and T. Saba, "Evaluation of artificial intelligent techniques to secure information in enterprises," Artificial Intelligence Review, vol. 42, no. 4, pp. 1029-1044, 2014.

[34] J. Park, J. Yang, and Y. C. Hsieh, "University level second language readers' online reading and comprehension strategies," Language Learning \& Technology, vol. 18, no. 3, pp. 148-172, 2014.

[35] R. Ploetzner, R. Lowe, and S. Schlag, "A systematic characterization of cognitive techniques for learning from textual and pictorial representations," Journal of Education and Learning, vol. 2, no. 2, pp. 78-95, 2013.

[36] S. M. Prior and K. A. Welling, "' Read in Your Head": A Vygotskian Analysis of the Transition from Oral to Silent Reading," Reading Psychology, vol. 22, no. 1, pp. 1-15, 2001. 
[37] J. Gläser and G. Laudel, "Life with and without coding: Two methods for early-stage data analysis in qualitative research aiming at causal explanations," in Forum Qualitative Sozialforschung/Forum: Qualitative Social Research, 2013, vol. 14, no. 2.

[38] J. Miller and P. J. Schwanenflugel, "Prosody of syntactically complex sentences in the oral reading of young children," Journal of educational psychology, vol. 98, no. 4, p. 839, 2006.

[39] Y.-F. Yeh, E. M. McTigue, and R. M. Joshi, "Moving from explicit to implicit: A case study of improving inferential comprehension," Literacy Research and Instruction, vol. 51, no. 2, pp. 125-142, 2012.

[40] S.-c. Hsu, "The reading strategies used by EFL technical students," English Teaching e-Monthly, vol. 22, no. 1, pp. 155-179, 2007.

[41] Phakiti, "A closer look at gender and strategy use in L2 reading," Language learning, vol. 53, no. 4, pp. 649-702, 2003.

[42] Phakiti, "A closer look at the relationship of cognitive and metacognitive strategy use to EFL reading achievement test performance," Language testing, vol. 20, no. 1, pp. 26-56, 2003.

[43] Poole, "Gender differences in reading strategy use among ESL college students," Journal of college Reading and Learning, vol. 36, no. 1, pp. 7-20, 2005.

[44] M.-C. Hu, "Hidden Transfer: Indicators of English Reading Performance among Taiwanese Students," Unpublished master's thesis, Da-Yeh University, Taiwan, 2006.

[45] H.-c. Huang, "EFL learners' online reading strategy use and text comprehension: An exploratory study," Unpublished doctoral dissertation, National Taiwan Normal University: Taipei, Taiwan, 2006.

[46] H.-C. Hung, "The Effects Of Sex And Language Material Styles On Reading Strategies Of Senior High School Students In Taiwan," Unpublished master's thesis, National Kaohsiung Normal University, Taiwan, 2001.

[47] W.-k. Kuo, "The proficiency and gender differences in reading strategies used by junior high school students toward the Basic Competence Test," Unpublished master's thesis, Providence University, Taiwan, 2003.

[48] J. Chen and S. H. Huang, "High-intermediate English proficiency learners' reading strategy use in comprehending different passages: A case study," in Proceedings of the 24th International Conference on English Teaching and Learning in the Republic of China, Taiwan, Taipei, 2007.

[49] H. F. Shang, "Reading strategy training for the development of Chinese EFL reading comprehension," in Proceedings of the 24th International Conference on English Teaching and Learning in the Republic of China, Taiwan, Taipei, 2007.

[50] L. Hsu, "A study of relationships between feeling of knowing about English reading strategy use and reading comprehension of Taiwanese college students," National Changhua University of Education, 2003.

[51] M. Green and R. Oxford, "A closer look at learning strategies, L2 proficiency, and gender," TESOL quarterly, vol. 29, no. 2, pp. 261-297, 1995.

[52] R. Oxford and M. Nyikos, "Variables affecting choice of language learning strategies by university students," The modern language journal, vol. 73, no. 3, pp. 291-300, 1989.

[53] T. Bidjerano, "Gender Differences in Self-Regulated Learning," Online Submission, 2005.

[54] Sy, "Gender differences, perceptions on foreign language learning and language learning strategies," in Twelfth National Conference on TESOL in the ROC, Tung High University, Taiwan, 1995.

[55] N.-D. Yang, "A study of factors affecting college EFL students' use of learning strategies," in eleventh conference on English teaching and learning in the Republic of China, 1994, pp. 53-82.

[56] H. Yu and M. Chen, "Motivation and learning strategy use among junior high school students with different levels of academic achievement," Unpublished master's thesis, National Pingtung Institute of Commerce, Taiwan, 2006.

Citation: Ching-Ying Lin, Yu Hung Pan. "The Impact of Reading Strategy Use on EFL College Students" International Journal on Studies in English Language and Literature (IJSELL), vol 7, no. 5, 2019, pp. 43-51. doi: http://dx.doi.org/10.20431/2347-3134.0705005.

Copyright: (C) 2019 Authors. This is an open-access article distributed under the terms of the Creative Commons Attribution License, which permits unrestricted use, distribution, and reproduction in any medium, provided the original author and source are credited. 